\title{
Legal Regulation of Arbitration Procedures in Securities Disputes at Amman Stock Exchange: Analytical Study
}

\author{
Dr. Ahmad Fahd Mohammad Albtoosh \\ Assistant professor at Faculty of Law, Ajloun National University
}

\begin{abstract}
This study addressed the legal provisions governing the arbitration procedures in the securities disputes at Amman Stock Exchange. It identified the legal procedures for activating the dispute by one of the parties to the dispute, the procedures for forming the arbitration tribunal, consideration of the arbitration case by this tribunal, and then issuing the ruling in the arbitration case. This study adopted a descriptive analytical approach to achieve its objectives. The study concludes that the Jordanian legal system has dealt with disputes arising from the trading of securities in the Amman Stock Exchange in acceptable manner, However, it would be preferable to amend paragraph A of Article 18 of "Instructions of Dispute Resolution through Arbitration at Amman Stock Exchange for the year 2018" concerning the manner of decision-making in the event that the arbitration tribunal does not reach a decision unanimously or by majority, where these instructions state that the president of Arbitration Tribunal shall solely issue the award. While it would have been better if it had provided for the formation of a new arbitration tribunal.
\end{abstract}

Keywords: Arbitration Procedures, Securities Disputes, Amman Stock Exchange, arbitration Tribunal, arbitral case.

DOI: $10.7176 / \mathrm{JLPG} / 85-18$

Publication date:May $31^{\text {st }} 2019$

\section{Introduction}

An arbitral conflict starts when one side of the conflict demands of arbitration procedures applies to Amman Stock Exchange secretary that he has the desire to resort to arbitration, which is the first point in the process of arbitration conflict whether there is a previous agreement among the conflict parties where the held securities agreement ensures that there is an arbitral condition be resort to when there is a conflict, or the parties agreed to hold a conditional arbitration after the conflict arises. Therefore, it can be said that the broker and client can resort to judiciary .

Because of the spread of securities trade in Jordan and importance, sensitivity and size of financial dealing, regulations of starting work were set systemically when there is a conflict in any form and mechanisms that ensure to end this conflict. The Jordanian legislator issued ( Instructions for Conflicts Solutions in Amman Stock Exchange of 2018), issued based on rulings of the article (24/B/7) of the internal system of Amman Stock exchange of 2004, and worked as of 1/9/2004 which was a step by the legislator to break up conflicts arise in stock exchange to arbitration.

To identify how to start arbitration procedures in Amman Stock Exchange beside viewing of conflict and ending with breaking it by jury based on instructions of conflicts solutions in stock exchange, and explaining the extent of arbitration process correspondence with Jordanian arbitration law, we will deal in this study the arbitration conflict progress in Amman Stock Exchange in addition to ending of the arbitration procedures in stock exchange.

\subsection{Problem Statement}

The study problem lies in one major question which is : "How legal regulation of arbitration procedures is completed in securities of Amman Stock Exchange ? Many questions branch from the major question which are the following:

1. How arbitration conflict progress is completed in Amman Stock Exchange?

2. How arbitration procedures ending are ended in Amman Stock Exchange?

\subsection{Significance of the Study}

The importance of the study lies in the following:

1. Showing the arbitration legal nature as an alternative means of Amman Stock Exchange conflicts breakup.

2. Identifying what the legislator has endorsed of legal procedures in a case of not finding a conflict solution by arbitration.

3. Identifying the extent of jury decision binding and how to challenge it and the mechanism of implementing it.

\subsection{Objectives of the study}

The current study aimed to answer the questions of the study mentioned in the study problem which are : 
1. How legal regulation of arbitration procedures is completed in securities of Amman Stock Exchange?

2. How arbitration conflict progress is completed in Amman Stock Exchange?

3. How arbitration procedures ending are ended in Amman Stock Exchange?

\subsection{Study Approach}

The descriptive approach will be adopted in this study through dealing with induction of the Jordanian legislations texts ( some of them are instructions of Amman Stock Exchange conflicts break up), and concentration on describing procedures that are completed inside Amman Stock Exchange when conducting arbitration as one means of in Amman Stock Exchange conflicts break up.

\section{The Beginning of Arbitration in Securities Disputes in the ASE}

If a conflict happens among parties of securities agreement, the arbitration conflict is held when the arbitration procedures start by any party of the agreement. In this case the complainant has the right to a apply for Amman Stock Exchange secretary showing his desire to resort to arbitration. I will deal starting with arbitration conflict in the following demands:

\subsection{Arbitration Procedures in Amman Stock Exchange}

Amman Stock Exchange arbitration procedures agree with the commercial arbitration procedures. We will deal with these procedures as follows:

\subsubsection{Submit an Arbitration Request}

The arbitration request means that the request which is applied by one of the parties of securities trade agreement in order to resort to arbitration, and the held written agreement should include an arbitral condition which states that all conflicts arise and ones related to should be solved according to rulings of instructions of stock exchange conflicts solutions by an individual arbitrator or more based on the two parties agreement, or if the two parties agree after the conflict arises to solve it based on rulings of instructions in case there is no arbitrational condition. If one of the two cases is available, the party that has the desire to start arbitration procedures has to apply to Amman Stock Exchange administrative board secretary showing his desire to start arbitrations procedures so that the secretary starts the procedures according to the instructions. To know the mechanism of starting of procedures progress, this branch will be discussed as follows :

\subsubsection{Starting Arbitration Procedures}

The article (4) of instruction of conflict solution of Amman Stock Exchange states that:

A-Each party who wants to resort to arbitration according to these instructions should apply to the secretary and should include the following information:

1. Name each of a prosecutor and defendant and his full address.

2. Related agreements particularly those related to agreement on reference the conflict to arbitration according to these instructions.

3. Description of the nature and circumstances of the conflict which is the cause of the applying the request.

4. An indication to the subject of the request, required amounts and evidences based on his allegation.

5. His position of the number of arbitrators and selection according to the rulings of article (6) of these instructions.

6. Any other information related to the subject of request.

So, the arbitration request is the act which the appellant starts showing his desire to break up the current conflict with the prosecutor through arbitration. The original is to direct such a request to the appellant since the arbitration is considered as a free arbitration not an organizational one ${ }^{1}$, but the instructions of solving conflicts in Amman Stock Exchange obliged the arbitration request to be presented to the stock exchange administrative board secretary, so that the latter supply the appellant with a copy of the request and attached documents in order to reply to the appellant demands mentioned in it ${ }^{2}$.

\subsubsection{Reply to the Request of Arbitration by the Defendant}

After the appellant applies the request of arbitration to Amman Stock Exchange secretary according to what has it contained of information and demands, the secretary provided the defendant with a copy of the request and its attachments the next day of completing documents presented by the prosecutor, and this is what has been confirmed by the article (4/B) of the instructions of Amman Stock Exchange conflicts solutions which states : "When the documents mentioned in item(A) of this article, the secretary provides the defendant the next day of completed documents with a copy of the request and attached documents to be replied to".

If the defendant receives the request of arbitration, he should reply within five days of his receipt, and to present his reply to the secretary. The reply should include the defendant's opinion about the nature of the conflict and his answer to what has been mentioned of prosecutor's demands and evidences relies on with his answer, and

\footnotetext{
(1) Fathi Wali(2006), Arbitration law in theory and practice, Manshat Alm'aref, Alexandria

${ }^{(2)}$ Hamza Ahmad Haddad(2010), Arbitration in Arab laws, Dar Athaqafa, Amman
} 
showing his opinion about the suggestions of the number of arbitrators and their selections in addition to an information related to the subject of the conflict.

Article (A/5) limited the instructions of Amman Stock Exchange conflict solutions including the defendant reply on the request of arbitration ${ }^{1}$ which states that: " the defendant should reply to the request within (5) days of receiving the request and replies to the secretary including the following information:

1. His opinion on the nature and conditions of the conflict.

2. His reply on the prosecutor's answer and documents and evidences he depends on.

3 . His reply to the suggestions presented about the number of arbitrators and selection.

4. Any other information related to the subject of conflict. ${ }^{2}$

The instructions of Amman Stock Exchange conflicts solutions followed the Jordanian arbitration law concerning the ability of the defendant of his reply to the prosecutor case, any demands or allegation on the request of arbitration ${ }^{3}$. The defendant can in the case the documents he depends on or pointed to in his reply when presenting the request, he should point to and present during the case view ${ }^{4}$.

Article (5/B) of the instructions of Amman Stock Exchange conflicts solution states the following:" the defendant attach with his reply to the request any analog allegation on the request of arbitration, and the analog allegation includes showing facts that led to its emergence and the appealed amount of money by analog.

In case that the defendant attaches the analog allegation with his regulation of allegation with the request of arbitration, the secretary sends a copy of the reply and attached documents and a copy of the analog allegation within five days to the prosecutor where the latter reply to him within five workday of receipt the analog allegation 5

The defects of the instructions of Amman Stock Exchange conflicts solutions are that don't deal with the need to provide the case regulations with or answer regulations of copies that contains number of arbitrators and parties as the Jordanian arbitration law states in article (29) as the follows: " The prosecutor sends the defendant and each arbitrator his case regulation within the agreed appointment between the two sides or which the jury appoints which includes his name, address, the name of defendant, his address and explanation of the case facts ...". The item (B) of the same article states :" The defendant sends the prosecutor and each arbitrator within the agreed appointment between the two parties or which the jury appoints ...." 6 .

\subsubsection{Formation of Jury}

The instructions of Amman Stock Exchange conflicts solutions don't state to mention the conditions should be available for an arbitrators or determining people who are not allowed to practice the role of an arbitrator following the Jordanian arbitration law in the article (15/B), and don't specify any conditions or should be enough available experience for an arbitrator who would be chosen to view conflicts related to securities and their trade, or even set rules for professional behavior of the arbitrators particularly, which leaves room for estimation of the administrative board chairman of Amman Stock Exchange without explaining the objective criteria which the selection has based on especially if we realized that the arbitrational work is considered from an economic area as a very attractive work, and seeking to it with all ways is an expected work ${ }^{7}$.

The selection of arbitrators is considered a right of arbitration parties. They have the right to agree on the selection, how to implement and its date ${ }^{8}$. The parties will as the Jordanian legislator depends on it through the formation of the jury is the considerable basis of this formation. Although the requirement of the number of arbitrators should be individual, the legislator doesn't specify the maximum number of arbitrators agreed on their selection by the parties of arbitration. They can select an individual arbitrator, three, five or more, but their number must be individual in line with the text, otherwise the arbitration would be invalid. In the case the parties don't agree on the number of the arbitrators, the legislator imposes that there should be three arbitrators ${ }^{9}$. The jury is chosen in conflicts of Amman Stock Exchange trade as follows:

\subsubsection{Selection of an Individual Arbitrator to View Conflict}

The article (6/A) of the instructions states as follows: "If the prosecutor and defendant agree that the conflict should be viewed by an individual arbitrator, they can appoint him in writing on an agreement and to be reported to the

\footnotetext{
(1) This trend is adopted by the instructions of Amman Stock Exchange conflicts solution and applied by Jordanian legislator in the article (29/B)

(2) The article (29/B) of the Jordanian arbitration law

(3) Mahmoud Ali Alrashdan(2016), Explanation of Jordanian arbitration law ,a rooting and analytical explanation of the law texts supported by legal principles of Jordanian Court of Cassation, Scientific Dar Alyazori.

(1) Items (C and D) of the article (5) of the instruction of Amman Stock Exchange conflicts solution

${ }^{(2)}$ The article (29/A) of the Jordanian arbitration law

(3)Tal'at Mohammad Dwedar(1992), Judgment securities in arbitration conflict, Addar Aljami'ya Aljadeeda , and Muhannad, Alsanori(2005), The role of arbitrator in the private world arbitration conflict - a comparative study of the world trade arbitration rulings in most of foreign and Arab legislations and Arab centers and agreements, Issue 1, Dar Athaqafa, Amman

${ }^{(4}$ Muhannad, Alsanori(2005), The role of arbitrator in the private world arbitration conflict - a comparative study of the world trade arbitration rulings in most of foreign and Arab legislations and Arab centers and agreements, Issue 1, Dar Athaqafa, Amman

(1) The article (14/A) of Jordanian arbitration law, look: Mohammad Abd Elkhalek Alzubi(2010), The arbitration law as an agreement judiciary legal system of a special kind attached to it the most important world arbitration legislations agreements, Munshat Alm'aref, Alexandria.
} 
secretary. If they don't agree on this designation within (7) days of the date of reporting the request of arbitration to the defendant, the administrative board chairman appoint the individual arbitrator".

Through the text, it is noticed that the Jordanian legislation in Jordanian arbitration law the parties have the complete freedom to select the number of the arbitrators whether they agree on an individual arbitrator or more to view the conflict ${ }^{1}$. The item (B)of the article (6) of the Jordanian arbitration law the difference between the Jordanian arbitration law position in selection of the number of arbitrators and the position of instructions of Amman Stock Exchange conflicts solution which states that :'If the two parties don't agree on designation an individual arbitrator, the conflict is referred to three arbitrators to be viewed in .....". The reference of arbitration to be viewed in by three arbitrators is obligatory in the case of the two parties don't agree to be viewed by an individual arbitrator when requesting arbitration first to the secretary and the defendant reply to the request of arbitration and not agreement of the parties from the beginning.

The Jordanian Court of Cassation decided the case of interference of Amman Stock Exchange administrative board in designation an individual arbitrator in a case there is an agreement on view the conflict by an individual arbitrator, but the disagreement is to name or appoint him in its decision :"Because of the documents of the case were free of the agreement of the two parties to appoint an individual arbitrator, the administrative board chairman has no right to appoint an individual arbitrator which refer us to item (2) of the previous article (6). What is stable is that there is no agreement between the two parties to appoint an individual arbitrator and thus, the conflict should be referred to three arbitrators to view where each party appoint an arbitrator, then the administrative board chairman appoints the third arbitrator, this means the formation of jury is contrary to rulings of instructions of Amman Stock Exchange conflicts solutions of (2004) which makes this reason probable of the challenged decision and should be revoked "2

\subsubsection{2 formation of jury of three arbitrators}

If the parties of the arbitration don't agree on view the conflict by only an individual arbitrator, therefore, the conflict should be referred to be viewed obligatory by three arbitrators. The instructions of Amman Stock Exchange conflict solution make stock exchange administrative board chairman whom to be responsible for appointing the third arbitrator. In the case the parties don't agree on transfer the appointed arbitrators by them to be chosen, and this is what the article (6/B) adopted with instructions of Amman Stock Exchange conflict solution which states that:" If the two parties don't agree on designation of an individual arbitrator, the conflict is referred to three arbitrators to view, and in this case each party requests for arbitration and reply to it by appointing an arbitrator on behalf of him. The administrative board chairman appoints the third arbitrator unless the two parties entitle the appointed arbitrators to select the third arbitrator within three days of the date of the second arbitrator appointment. If the two arbitrators can't agree to select the third arbitrator within the mentioned period, the administrative board chairman appoints him and the third arbitrator take responsibilities of all of jury conditions of presidency".

It is observed of above that in a case that the parties don't agree on view the conflict by an individual arbitrator, then the arbitration is resorted to three arbitrators which each party chooses its arbitrator, and thus to choose the third arbitrator by the appointed arbitrators if the parties agree to entitle them. If the parties don't agree on this entitlement, the third arbitrator is selected by stock exchange administrative chairman.

\subsection{View of Arbitration Case}

The article (24) of Jordanian arbitration law states that: "The two parties of arbitration can agree on procedures which the jury follow including their right to subject such these procedures to the followed rules in any institution or arbitration center inside or outside the Kingdome. If such an agreement isn't found, the jury can choose the suitable arbitration procedures subject to the rulings of the law".

The instructions of Amman Stock Exchange conflict solution states that the procedures should subject to its private rulings in front of the jury when they decided in the article (13/A) that: " The procedures view by the jury are subject to these instructions, and in cases that have no text in these instructions refer to the related Jordanian legislations". The instructions also according to item (B) of the same article confirm that related Jordanian legislations should be applied on the subject of the conflict regarded that the arbitration process happens in the Kingdome and related to an existent conflict.

The secretary submit the conflict file to the arbitrator or jury as appropriate to view the conflict after completing exchange of regulations and documents and appointing arbitrators ${ }^{3}$. The arbitrator or jury assign clerks for hearings first, and study the case in the light of regulations and documents presented by parties. The jury has the right to hear the parties sayings even if they aren't asked to do that. The jury also has the right to listen to any person's witness that see a reason for hearing him with a condition that will happen with attendance of the two

\footnotetext{
(2The article (14) of Jordanian arbitration law, and article (6) of the instruction of Amman Stock Exchange conflicts solution

${ }^{(1)}$ Right Cassation 2830/2013, date 18/3/2014- Jordan Cassation Rights Court registry

${ }^{(1)}$ The article (7/A) of the instruction of Amman Stock Exchange conflicts solution
} 
parties or after inviting them ${ }^{1}$.

Amman Stock Exchange's instructions took in consideration the failure to attend the meetings by any of the parties so as to achieve the principle of justice and equality between them although of reporting him of the appointment as appropriate and the followed procedures if his absence for an acceptable excuse. It is a contrary concept of the item (B) of the article (8) of the instructions which they state: "If any of the two parties failed to attend the hearing in spite of sending for him as appropriate, the jury after ensuring that there is no acceptable excuse has the right to continue its mission and consider that the procedures have completed in the face of the two parties". It should reconsider the procedures that are completed during the absence of the party that has an acceptable excuse according to the jury estimation, otherwise all of the procedures completed are considered true and happened in face of the two parties

The item (A) of the article (9) of the instructions of Amman Stock Exchange conflicts solution related to the place of arbitration states that :" The place of arbitration will be in Amman and the stock exchange will be the headquarters of the arbitration procedures unless the parties agree unlike that", ${ }^{2}$ and by this it made Amman a place for arbitration in stock exchange conflicts emerged between the financial agent and client, unless the two parties agree to choose another place. While item (B) of the same article considered Arabic Language as the arbitration language which states: "Arabic Language is the arbitration language unless the two parties adopt another language" ${ }^{3}$.Concerning the progress of procedures in the face of the jury, the item of the same article states : "The jury is responsible for the progress of hearings, and none is allowed to attend only the two parties or their legal representatives (lawyers) only with the consent of the jury ${ }^{4}$.

The jury chairman and hearings clerk must sign the arbitrational case transcripts. The item (D) of the article (9) of instructions of Amman Stock Exchange conflicts solution states that : "The hearing transcripts must be signed by the jury chairman and hearings clerk", ${ }^{5}$ and by this it doesn't deal with the rest of jury members signature in the case the jury was formed of three arbitrators. Although the Jordanian arbitration law doesn't mention that the jury should sign the hearings transcripts in its texts and satisfied with the text that it ought to record these transcripts, but the jury and based on the rulings of the article (1/80) of the Civil Procedure Law must sign the hearings transcripts to ensure the safety of procedures progress and full attendance of the jury members who view the conflict.

\section{End of Arbitrational Procedures in Amman Stock Exchange}

The desired goal of the arbitrational case is to end the conflict and access to a final judgment, which all of the conflict parties seek to in order to each party get what it has claimed and presented its evidences to prove its right. This needs the jury since it is trusted by all of the parties when they chose it to bring each right holder his right within the limited period whether it is an agreement or legal ${ }^{6}$.

The arbitration judgment as the legal judgment. It must be clear and conclusive in its operative form, and in a manner that doesn't leave any doubt in its determining of the rights and duties of the parties in the arbitrational case where the judgment will be replied to all of the litigants requests positively or negatively, otherwise it will be a subject to challenge by the result, ${ }^{7}$ through the two following requirements:

\subsection{Issue of Arbitration Judgment}

After the end of procedures that should be followed in the arbitration case, the arbitrator or the jury are obliged to issue their judgment in the conflict within the limited period. In order to reach that, it will show the most important work by the jury to issue its decision as follows:

\subsubsection{The Deliberation}

Deliberation is considered the first procedures which is done by the jury through the deliberation among its members when agree on the final judgment which will be issued by the case through the jury members debating and exchanging their opinions in all evidences and requests presented by the arbitrational case parties in order to form its faith in the conditions of the case before the final verdict of the case ${ }^{8}$. In addition to the exchange of views in the legal rules that should be applied on the conflict presented to the jury ${ }^{9}$.

\footnotetext{
${ }^{(2)}$ The article (7/B) of the instruction of Amman Stock Exchange conflicts solution

(1) The article (9/A) of the instruction of Amman Stock Exchange conflicts solution

(2) The article (9/B) of the instruction of Amman Stock Exchange conflicts solution

${ }^{(3)}$ The article (9/C) of the instruction of Amman Stock Exchange conflicts solution

(4) The article (15/D) of the instruction of Amman Stock Exchange conflicts solution

(1) Ahmad Alsayed Sawi(2002), Arbitration according to Law 27 of 1994 and world arbitration systems, Publisher : Ahmad Alsayed Sawi, Cairo

(2) Hamza Ahmad Haddas, Arbitration in Arab countries, p 383

(3) Ahmad Alsayed Sawi(2002), Arbitration according to Law 27 of 1994 and world arbitration systems, Publisher : Ahmad Alsayed Sawi, Cairo, p 171

(4) Mohammad Abd Elkhalek Alzubi(2010), The arbitration law as an agreement judiciary legal system of a special kind attached to it the most important world arbitration legislations agreements, Munshat Alm'aref, Alexandria, p251
} 
The instructions of Amman Stock Exchange conflicts solution don't point to the deliberation among the jury members ${ }^{1}$. It is understood from the article text (15/A) of the instructions which states that: "If three arbitrators are appointed, the arbitration decision will be taken unanimously or by majority ...." of the obligation of deliberation among the jury members to reach a final judgment ending of the conflict according to what has been shown by the article (15/A) of the instructions of Amman Stock Exchange conflicts solution.

The jury members deliberation must be confidential although there is no text adjudicates with this. The confidential of the deliberation is considered one of the arbitration major principles, so the deliberation among the jury members must be confidential to reach a final judgment of the conflict ${ }^{2}$.

The deliberation should be completed among all of the jury members. It isn't expected to be completed between the jury chairman and one of the members in isolation from the third member if the jury is formed of three arbitrators, it is possible that the deliberation among the jury members by E-Mail, telephone or fax without their meeting in one place, and the deliberation can be completed orally or written when they meet in one place ${ }^{3}$.

If the deliberation process is completed among the jury members on the decision which should be issued in a case the jury doesn't agree on one opinion about it, then it is resorted to voting, and this is what the article (15/A) decided in the instructions of Amman Stock Exchange conflicts solution which explained the way of decision making to end the conflict by the jury formed of three arbitrators when it adopted both cases of consensus or majority among the jury members. In case of the absence of any of the two cases, the instructions adopted on the case when the jury chairman issues an individual decision on the contrary to what the Jordanian arbitration law adopts.

The signature of all of the jury members on the decision is considered as an evidence of the deliberation conduction among them and involving them in the deliberation. The abstention of a member of the jury to sign the decision because it disagrees the majority opinion or fixing his disagreement by an attached note and signed by him as an evidence of the deliberation conduction among the jury members. According to this, the challenge is not allowed to conduct the deliberation but only in challenge of fraud because the arbitration decision is considered as an official document that its content can't be proved but only through challenge of fraud ${ }^{4}$.

\subsubsection{Reasoning of the Decision}

The item (B) of the article (15) of the instructions of Amman Stock Exchange conflicts solution obliged the jury of the reasoning the decision issued by it. It states that: "The decision must be reasoning". Since the reasoning of a decision is considered one of the litigation collateral for the arbitrators, it ensures the extent of their understand of the conflict facts and the requests of arbitrational case parties, and showing the good performance of the jury's mission which it carried out through showing the fact and legal reasons which led to issue the judgment ${ }^{5}$, and the judgment reasoning is considered the best ensuring of litigants in facing the jury and motivate them to pay attention and be accuracy when issuing their decision that ends the conflict, on the other hand ${ }^{6}$.

The jury has plenipotentiary in reasoning its decision without commitment to adopt what the parties have addressed of reasons through their requests and defenses in the case. It has the right to adopt the reasons which it considers proper but with a condition that the reasoning must be built on fixed facts in the file of the arbitration case, and it is derived logically from the arbitration case and the reasoning leads to results that have been found in the final decision by the jury ${ }^{7}$.

\subsubsection{Place and Date of a Decision Issue}

The item (c) of the article (15) of instructions of Amman Stock Exchange conflicts solution states that: "the arbitration decision is considered to be issued in the place of arbitration and on the date of its issuing". The origin according to instructions of Amman Stock Exchange conflicts solution is what the parties choose to be a place for arbitration. If the parties agree on locating a specific place and made it a place for arbitration, such an agreement will be binding to the parties and jury. But in a case of absence of parties agreement, the place of arbitration is Amman city, and Amman Stock Exchange is the headquarter to conduct the arbitrational process.

This what instructions of Amman Stock Exchange conflict solutions have adopted when decided in the article (9/A) that: "the place of arbitration is in Amman and the stock exchange will be the headquarter of the arbitration procedures unless both the parties agree otherwise". So, the lesson is in the parties agreement to specify the place

\footnotetext{
${ }^{(5)}$ Jordanian Arbitration Law also doesn't mention the trade matter among the jury members in the article (38) and the arbitration system Stock Exchange and conflict solutions in Damascus followed the instruction of Amman Stock Exchange conflicts solution that it doesn't mention the matter stock exchange trade among the jury members

(1) Ahmad Alsayed Sawi(2002), Arbitration according to Law 27 of 1994 and world arbitration systems, Publisher : Ahmad Alsayed Sawi, Cairo, p 173

${ }^{(2)}$ Fathi Wali, The law of arbitration in theory and practice, $\mathrm{p} 429$

${ }^{(1)}$ Fathi Wali, The law of arbitration in theory and practice, $\mathrm{p} 431$

(2) Mohammad Ali Bani Meqdad(2013), The correct approach to issue and implement arbitration judgment: a comparative applied theoretical study, Hamada Institution for university studies , publications and distributions, Dar Alyazori, Irbid, Jordan : Amman, Jordan

(3) Ahmad Alsayed Sawi(2002), Arbitration according to Law 27 of 1994 and world arbitration systems, Publisher : Ahmad Alsayed Sawi, Cairo, p 185

${ }^{4)}$ Hamza Ahmad Haddad , Arbitration in Arab countries, 402
} 
of arbitration and their freedom in selection and the need to respect the jury for their agreement on that. But in the case of absence of such an agreement, the instructions of Amman Stock Exchange conflicts solution obliged to make Amman the place for arbitration and the stock exchange a headquarter for its procedures which leads to that the jury needs to follow what have mentioned in the text and consider the stock exchange a headquarter for arbitration. In this direction and for the absence of parties agreement, the jury dealt with problem from the three arbitrators in its arbitration decision issued on the emergent conflict between the parties as a result of treatment in buying and selling stocks where it is issued in its decision that the place of arbitration will be in Amman Stock Exchange based on rulings of article (9/A) of instructions Amman Stock Exchange conflicts solution ${ }^{1}$.

Amman Court of Appeal considered that when the individual arbitrator holds the arbitration hearings in his own office in Amman city is compatible with what instructions of Amman Stock Exchange conflicts solution state for the impossibility of conducting arbitration procedures in the stock exchange headquarter because of coincidence of market employees sit-in at that time since the system adopted the arbitrational process procedures and the arbitrator applied the Jordanian arbitration law to replenish in the system of Amman Stock Exchange that his decision will be compatible with law ${ }^{2}$.

The lesson of specifying the date of issuing the judgment is to define the date that the results of judgment go through and identifying if the judgment is issued in the definite time which the instructions of Amman Stock Exchange conflicts solution state. The article (14/A) of instructions state that : " the jury must issue the final arbitration decision within (20) days of the presented file date", and the item (B) of the same article granted validity of extension of the mentioned period to a similar one to the stock exchange administrative board according to a satisfactory request with the jury. If a decision of the jury is issued after the expiry of the limited periods in the article (14) of the instructions, it has been issued after vanishing the authority of arbitrators in issuing it ${ }^{3}$, which enables one party of the conflict which the judgment has been issued against him to resort to the ordinary judiciary in this case to demand of the subject of right which is the arbitrational case subject.

\subsubsection{Signature of the Jury}

The article (15/D) of instructions of Amman Stock Exchange conflicts solution states that : "The arbitration decision is issued in writing and signed by the jury". The decision that ends the conflict should be issued in writing by the jury. It can't be expected when carrying out the decision for the specialized court that such a decision is orally because it is impossible to carry it out in this case even the arbitration case parties agree on non- issuing the decision ${ }^{4}$. The jury members ought to sign it when it is issued consensually, and it is enough to be signed by the majority of the jury members and to mention the reason of refusing of the minority to sign the decision ${ }^{5}$.

It is allowed if a minority of arbitrators to show the reason for a disagreement whether in the judgment itself or in a single paper to show the reason for refusing which isn't compatible with the majority opinion and show its legal view that disagrees the majority opinion with showing the reasons for this opinion ${ }^{6}$.

However, the judgment signed by the majority of the jury members is still the decision that is interested in when implementing it even if it isn't attached with the disagreement decision issued by the minority of disagree arbitrators.

As the decision is completed by signature of all or majority of the arbitrators, the judgment is considered to be fulfilled its formal base, which its failure lead to invalidity of arbitration judgment ${ }^{7}$.

\subsection{Binding Force of a Decision and its Implementation}

The article (52) of Jordanian arbitration law states that: "The arbitration judgments issued according to this law possesses binding force of the adjudicated matter and it is enforceable considering the provided texts". Based on this, the arbitration judgments possesses binding force as soon it is issued binding force of the adjudicated matter even there is no order issued to implement it and this binding force still remains as long as the judgment remains 8 .

Since the arbitrators judgment possesses the binding force of adjudicated matter which doesn't means that the matter is able to be implemented even if it's implemented by dispute ${ }^{9}$

Although what the article (52) of Jordanian arbitration law has adjudicated, the researcher thinks that the

\footnotetext{
(1) The arbitrational decision issued by the majority of the jury formed by three arbitrators on 8/6/2009, Amman Stock Exchange

(2) Amman Rights Cassation 43/2012 date request 22/5/2013, Amman Rights Cassation Court Registry

(1) Mohammad Ali Bani Meqdad(2013), The correct approach to issue and implement arbitration judgment: a comparative applied theoretical study, Hamada Institution for university studies, publications and distributions, Dar Alyazori, Irbid, Jordan : Amman, Jordan , p 100

${ }^{(2)}$ Mohammad Ali Bani Meqdad(2013), The correct approach to issue and implement arbitration judgment: a comparative applied theoretical study, Hamada Institution for university studies , publications and distributions, Dar Alyazori, Irbid, Jordan : Amman, Jordan , p 112

(3) Ahmad Abu Alwafa (1990), Arbitration in Arab laws, Nashat Alma'aref, Alexandria

(4) Fathi Wali, The law of arbitration in theory and practice, p442

(5) Hamza Ahmad Haddad,Arbitration in Arab countries, p 412

(1) Abdel Hadi Abbas and Jehad Hawwash(1982), Arbitrations : Voluntary arbitration, obligatory arbitration, Arbitration in world conflicts, arbitration in world trade, judiciary thought, Damascus

(2) Mohammad Abd Elkhalek Alzubi(2010), The arbitration law as an agreement judiciary legal system of a special kind attached to it the most important world arbitration legislations agreements, Munshat Alm'aref, Alexandria
} 
arbitrational case parties in a conflict related to the agreement of stock exchange trade and for their sake, have the right to resort to the judiciary or presenting another arbitration request to the stock exchange administrative board secretary based on the procedures which the instruction of Amman Stock Exchange conflict solution state in the a matter of what the previous arbitration has adjudicated and reforming the jury which has issued the previous judgment or a different jury without any restrictions as this they agree on. The jury or even the court which don't possess the matter that the previous arbitration was viewed by them to adjudicate by themselves refuse the case because of the proceeded judgment of the conflict subject since the judgment in the conflict is completed according to what the parties have agreed on without compliance of the law rulings ${ }^{1}$.

\section{Conclusions and Recommendations}

\subsection{Conclusions}

1. Amman Stock Exchange jury is formed by one arbitrator in a case it is agreed upon, or three arbitrators to take their decision based on the item (A) of the article (15) of the instructions of Amman Stock Exchange conflict solution.

2. In a case of a prosecutor doesn't present his case within the limited period, the jury can end arbitration procedures unless both the parties agree otherwise.

3. There are no limited of the previous experiences required for the arbitrator, and there are no limited on arbitration costs in Amman Stock Exchange.

\subsection{Recommendations}

1. The researcher wishes the Jordanian legislator to adjust the item (A) of the article (15) of the instructions of Amman Stock Exchange conflict solution of 2004 which states that : " A- If three arbitrators are appointed, the arbitration decision is taken consensually or by the majority and if the two cases aren't available, the jury chairman issues a decision individually", to become ...... If the two cases aren't available, the administrative board chairman dissolute the jury and it is reformed again".

2. The need to a previous agreement on the number of arbitrators and the required experience for arbitrators and specify the elements of arbitration cost by adding an item to Article (15) of the instructions of Amman Stock Exchange conflict solution of 2018).

\section{References}

1. Ahmad Abu Alwafa (1990), Arbitration in Arab laws, Nashat Alma'aref, Alexandria.

2. Ahmad Alsayed Sawi(2002), Arbitration according to Law 27 of 1994 and world arbitration systems, Publisher: Ahmad Alsayed Sawi, Cairo.

3. Instructions of Amman Stock Exchange conflicts solution.

4. Hamza Ahmad Haddad (2010), Arbitration in Arab laws, Dar Athaqafa, Amman.

5. Tal'at Mohammad Dwedar(1992), Judgment securities in arbitration conflict, Addar Aljami'ya Aljadeeda.

6. Abdel Hadi Abbas and Jehad Hawwash(1982), Arbitrations : Voluntary arbitration, obligatory arbitration, Arbitration in world conflicts, arbitration in world trade, judiciary thought, Damascus.

7. Fathi Wali(2006), Arbitration law in theory and practice, Manshat Alm'aref, Alexandria.

8. Decision of Amman rights Appeal 43/2012 date request 22/5/2013, Amman rights Appeal Court Registry.

9. The arbitrational decision issued by the majority from the jury formed of three arbitrators on $8 / 6 / 2009$, Amman Stock Exchange.

10. Mohammad Abd Elkhalek Alzubi(2010), The arbitration law as an agreement judiciary legal system of a special kind attached to it the most important world arbitration legislations agreements, Munshat Alm'aref, Alexandria.

11. Mohammad Ali Bani Meqdad (2013), The correct approach to issue and implement arbitration judgment: a comparative applied theoretical study, Hamada Institution for university studies, publications and distributions, Dar Alyazori, Irbid, Jordan : Amman, Jordan.

12. Mahmoud Ali Alrashdan(2016), Explanation of Jordanian arbitration law, a rooting and analytical explanation of the law texts supported by legal principles of Jordanian Court of Cassation, Scientific Dar Alyazori.

13. Muhannad Alsanori(2005), The role of arbitrator in the private world arbitration conflict - a comparative study of the world trade arbitration rulings in most of foreign and Arab legislations and Arab centers and agreements, Issue 1, Dar Athaqafa, Amman.

\footnotetext{
${ }^{(3)}$ Fathi Wali, The law of arbitration in theory and practice, $\mathrm{p} 461$
} 